\title{
Forgiveness Analysis of Domestic Violence Victims in Aceh
}

\author{
Putri Fakhrina Sari ${ }^{1}, \operatorname{Afdal}^{2}$ \\ ${ }^{1}$ Universitas Negeri Padang, ${ }^{2}$ Universitas Negeri Padang \\ *Corresponding author, e-mail: afdal@konselor.org
}

\begin{abstract}
Forgiveness in this study is an apology from victims of domestic violence to perpetrators of domestic violence. The number of cases of domestic violence that occur is increasing from year to year, as victims of domestic violence choose to maintain their household, even though the victim is undergoing a household that experiences violence. Many ways are used by victims in maintaining their household, one of them is by giving forgiveness to perpetrators of domestic violence. This study aims to analyze how forgiveness of victims of domestic violence in Aceh province. The method used is the quantitative approach and the type of comparative descriptive research. The population in this study was the wife who was a victim of domestic violence in the city of Banda Aceh by taking a sample using a purposive sampling technique, the sample in this study was 31 victims of domestic violence. This study uses a self-composed instrument namely Forgiveness Scale for Domestic Violence (FosDiV) developed from the TRIM-18 questionnaire using a Likert scale model. Data analysis techniques in this study used quantitative descriptive. The results of this study indicate that overall forgiveness of victims of domestic violence in Aceh is in the medium category, which means they assume that giving forgivenees to perpetrators of domestic violence is a natural thing to do as a wife. In Aceh culture, a wife who is obedient and obedient to her husband is very important, wives feel happy when they are called by the term "meutuah" wife. The word "meutuah" is well-liked by wives in Aceh. Besides that, it can be seen that victims who do not work more to close their cases for fear of not being supported by the perpetrators and feel that victims must depend on the perpetrators so that victims decide to maintain their domestic relations by apologizing to the perpetrators. Whereas victims who have their jobs are braver to report their cases and even choose to divorce and criminalize the perpetrators. It is hoped that the results of this research can help community institutions and other communities to jointly pay attention to the situation of victims of domestic violence and immediately report the case to the authorities, and can help victims of domestic violence to be able to lead a better life.
\end{abstract}

\section{Keywords: Forgiveness, Domestic Violence Victims.}

How to Cite: Sari, P.F., Afdal. (2020). Forgiveness Analysis of Domestic Violence Victims in Aceh. International Journal of Research in Counseling and Education. 4 (2): pp. 131-138, DOI: $10.24036 / 00314 z a 0002$

This is an open access article distributed under the Creative Commons 4.0 Attribution License, which permits unrestricted use, distribution, and reproduction in any medium, provided the original work is properly cited. $@ 2019$ by author.

\section{Introduction}

The formation of a family can occur because of culture and is the current life cycle (Munawwar, Muhammad, \& Sjafei, 2013). A family not only unifies the relationship of husband and wife, but also can unite all the differences that exist between them, in this case it can be said that a household that is fostered by husband and wife from time to time will not have the same attitude, personality and other factors (Leo, 2010). Husband and wife couples with marriage ages of 6-10 years are more likely to face differences, such as parenting, changes in positive attitudes that are lost after a long marriage and changing communication between couples (Saidiyah \& Julianto, 2016). Problems in the household if it cannot be resolved will be detrimental to several parties, even to the point of cases of domestic violence (domestic violence). Generally the victims of domestic violence are women (wives). Domestic violence (domestic violence) is a problem that often occurs in the container of the household, especially against women due to the patriarchal culture still thick in Indonesian society, norms, cultural values, even the law tends to always give greater power and power to the people men than women (Basri, S.Kasim, \& Roslan, 2018; Hanifah, 2007). 
Domestic violence is abusive behavior such as the intentional use of physical force in a relationship by a husband to be able to maintain power and control over his wife and cause physical, sexual, psychological, or neglect or suffering (Afdal, Alizamar, Ifdil, Erlamsyah, \& Taufik, 2017; Hossain, 2016; Santoro, MartínezFerrer, Gimeno, \& Musitu, 2018). In 1970 this case had become a worldwide discussion (Zikra, 2019). Considering the high number of domestic violence cases currently occurring and the impact on victims of domestic violence results in losses that are not only emotionally damaged but have an impact on their psychological functioning. Rates of violence against women in Aceh Province are dominated by domestic violence (domestic violence) (P2TP2A, 2019). As for several causes of domestic violence can be triggered by the number of children in the household, economic problems, communication in the household and patriarchal culture (Jayanthi, 2009; Maisah, 2016; Setiawan, Bhima, \& Dhanardhono, 2018). Some of the causes of domestic violence are also caused by the culture of society that is still thick with the principle that men are stronger and women are weak (Rofiah, 2017).

The most common cases of violence in Aceh Province are cases of domestic violence (domestic violence). Initially the domestic violence case was difficult to uncover, this was due to the notion that domestic violence was a disgrace in the household, so this problem was considered internal, taboo, sacred to be spread among the community (Nurrachmawati, Nurohma, \& Rini, 2013). Victims of domestic violence are afraid of the risk if he reports the case because the perpetrator is increasingly dangerous, such as the perpetrator reveals family secrets and it will make the victim feel ashamed, given the life of the child later, the family economy because the wife does not work even threatened by her husband if reporting it (Kaur \& Garg, 2008). These things make the victim to cover up the problem, so the victim chooses to stay afloat and always apologizes to her husband. The decision chosen by some wives is often called forgiveness, which in Indonesian is forgiveness. Forgiveness is a way to reduce negative impulses that damage a relationship (Mccullough, 2001). Forgiveness given by victims of domestic violence wife to perpetrators of victims of domestic violence is influenced by several factors, including marriage commitments, length of marriage that has been fostered, socioeconomic status, and worrying about the fate of their households, children, families (Ariyani \& Qonita, 2018; Mccullough et al., 1998; Prianto, Wulandari, \& Rahmawati, 2013; Worthington, 1999). Domestic violence certainly has a negative impact on victims, both physical and psychological. In general, these impacts include fear, anxiety, fatigue, abnormalities, post traumatic stress, depression, and eating and sleep disorders which are long reactions from violence (Ramadani \& Yuliani, 2015). In addition, the impact of depression felt by the victim will hamper his ability to live life (Alizamar et al., 2018; Zikra, 2019). Acts of domestic violence experienced by victims will also have an impact on lack of self-confidence, hampering the ability to participate in social activities, disrupt their health, reduce autonomy, both in the economic, political, sociocultural and physical fields (Pasalbessy, 2010).

Some victims of domestic violence choose to remain silent and not report the case to the authorities. The victim chose to remain silent and close the case because she felt the case was a disgrace to the family, the economic dependence of the victim on the perpetrators of domestic violence, was not ready to divorce because of the condition of the child and family (Kaur \& Garg, 2008; Nurrachmawati et al., 2013). Some victims of domestic violence choose to survive and give forgiveness (forgiveness) to their husbands. Forgiveness is the replacement of negative emotions with other positive emotions such as empathy, sympathy, affection and love (Worthington, 1999). Forgiveness given by the victim by eliminating his anger to the offender and can foster good relations with the offender without any sense of wanting to hurt again (Fuad Nashori, 2012). victims of domestic violence will forgive the offender for causing pity, compassion and affection, it may be that the perpetrator remembers the initial incident they met and committed each other in the household so that the victim unconsciously starts to bring affection to the culprit (Sumiati \& Sandjaja, 2013).

Forgiveness given by victims of domestic violence to offenders does not just appear. One of them is influenced by the victim's evaluation of the perpetrator, the victim's evaluation of the incident, the severity of the incident and the desire to stay away from the perpetrator (Rahayu, 2019). Other factors that can affect forgiveness are empathy, personality, having gratitude for what they have, resilience in managing adversity, upholding religious values and having relationship satisfaction (Elvinawanty \& Mailani, 2016). On the other hand according to Mccullough (2003) these factors are empathy, attack characteristics, personality type, relationship quality with the perpetrator, and religiosity. Not much different from the above opinion, it can be said that the victim's empathy for the perpetrator, the form of the attack given by the perpetrator, how the victim's relationship with the perpetrator and religion influence the victim to apologize to the perpetrator. Indicators of forgiveness are "making peace with people who have hurt, eliminating anger and hatred, throwing away the desire to get revenge and throwing attitudes to keep distance (Jampolsky, 2001). Besides forgiveness indicators of victims of domestic violence can be seen from the behavior of victims in leaving 
feelings of anger, hurt, hate, being able to control emotions when treated unpleasantly, leaving the desire for revenge, not avoiding the perpetrators and leaving the behavior indifferent (F Nashori, 2014).

Based on the description of the problem above, the phenomenon of domestic violence which is a case is very alarming at this time to be investigated, because many victims have suffered losses, some victims even choose to divorce and some are still surviving in their households so that victims choose to forgive, it is certainly based on several factors. Based on this, the writer wants to understand more deeply about the forgiveness analysis of victims of domestic violence in Aceh Province.

\section{Method}

The writing of this article uses a quantitative approach and comparative descriptive research. The sample in this study were victims of domestic violence aged between 26-56 years, with a marriage between 5-10 years and over. This research was conducted in the city of Banda Aceh with 31 victims of domestic violence. The data analysis techniques in this study were quantitative descriptive. The instrument in this study uses the Forgiveness Scale for Domestic Violance (FosDiV) developed from TRIM-18 instrument, with 4 choices of answers that are very appropriate, appropriate, not appropriate and very incompatible, which measures avoidance motivations namely the behavior of victims of domestic violence to avoid perpetrators of domestic violence, both physically and psychologically. Then revenge motivations, namely to measure the behavior of revenge victims of domestic violence to perpetrators and benevolence motivations, namely good behavior of victims of domestic violence to perpetrators of domestic violence.

\section{Results and Discussion}

The overall categorization of the forgiveness level of victims of domestic violence can be seen from the low, while the high score of the items they have, can be seen in the table below.

Table 1. Categories of Forgiveness Rates of Domestic Violence Victims

\begin{tabular}{|c|c|c|}
\hline Span & Category & Amount \\
\hline $91-112$ & Height & 7 \\
\hline $69-90$ & Medium & 14 \\
\hline $47-68$ & Enough & 10 \\
\hline
\end{tabular}

Based on the table above, it can be seen from 31 victims of domestic violence there are 7 victims of domestic violence with a high forgiveness category, 14 of them are categorized as moderate and 10 others are sufficient. So it can be said that of the 31 victims of domestic violence most of them are in the moderate category (S), meaning that victims of domestic violence assume that forgiving (forgiveness) to husbands who commit domestic violence is a natural thing given as a wife. In aceh culture there is the term "meutuah" which means both in this world and in the hereafter, someone who is said to be "meutuah" is someone who is considered loyal, obedient, and when involved with a relationship, he tends to give everything (Namamia, 2015). The description of forgiveness based on avoidance motivations, revenge motivations, and benevolence motivations sub-variables can be seen in the following table.

Table 2. Descriptive Forgiveness Victims of Domestic Violence in terms of Sub Variables

\begin{tabular}{|c|c|c|c|c|c|c|c|c|}
\hline \multirow[b]{2}{*}{ Sub Variable } & \multicolumn{7}{|c|}{ Score } & \multirow[b]{2}{*}{ Ket } \\
\hline & $\begin{array}{l}\text { Mak } \\
\text { simal }\end{array}$ & Highest & Lowest & Total & Average & $\%$ & SD & \\
\hline $\begin{array}{l}\text { 1. Avoidance Motivations } \\
(9)\end{array}$ & 34 & 36 & 15 & 780 & 25,16 & 69,89 & 5,58 & M \\
\hline $\begin{array}{l}\text { 2. Revenge Motivations } \\
\text { (11) }\end{array}$ & 44 & 43 & 19 & 939 & 30,29 & 68,84 & 7,37 & $\mathrm{M}$ \\
\hline \multirow[t]{2}{*}{$\begin{array}{l}\text { 3. Benevolence } \\
\text { Motivations }(8)\end{array}$} & 32 & 32 & 16 & 713 & 23,00 & 4,59 & 71,88 & $\mathrm{M}$ \\
\hline & 112 & 111 & 50 & 2432 & 78,45 & 70,05 & 17,18 & M \\
\hline
\end{tabular}

Based on the table above, it can be seen that each sub variable of forgiveness for victims of domestic violence is in the moderate category (M). On the benevolence motivations sub variable has the highest 
percentage compared with other sub variables, namely with a percentage value of $71.88 \%$, the second highest sub variable is avoidance motivations with a percentage of $69.89 \%$ and the last is revenge motivations with a percentage of $68.84 \%$.

In more detail, the results of forgiveness of victims of domestic violence based on sub-variables will be explained in each statement item as follows.

Table 3. Categories of Forgiveness Rates of Victims of Domestic Violence Based on Statement Items

\begin{tabular}{|c|c|c|c|c|}
\hline \multirow[b]{2}{*}{ Sub Variable } & \multirow[b]{2}{*}{ Statement } & \multicolumn{2}{|c|}{ Score } & \multirow[b]{2}{*}{ Category } \\
\hline & & Mean & SD & \\
\hline \multirow{9}{*}{$\begin{array}{l}\text { Avoidance } \\
\text { Motivations } \\
\text { (9) }\end{array}$} & $\begin{array}{l}\text { 1. Never tell about the incident } \\
\text { of violence that the husband } \\
\text { committed with family / } \\
\text { children and neighbors. }\end{array}$ & 2,68 & 0,65 & M \\
\hline & $\begin{array}{l}\text { 2. Choose to leave while out of } \\
\text { the house if there is a } \\
\text { conflict. }\end{array}$ & 2,77 & 0,76 & M \\
\hline & $\begin{array}{ll}\text { 3. } & \begin{array}{l}\text { Don't fight so the } \\
\text { atmosphere doesn't get } \\
\text { worse }\end{array} \\
\end{array}$ & 2,77 & 0,84 & M \\
\hline & 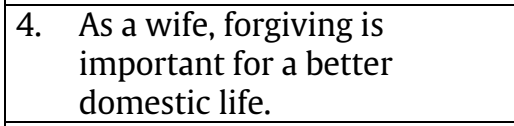 & 2,84 & 0,69 & M \\
\hline & $\begin{array}{ll}5 . & \text { Ask the family to reconcile } \\
\text { me and my husband. }\end{array}$ & 3,00 & 0,68 & M \\
\hline & \begin{tabular}{|l} 
6. \\
$\begin{array}{l}\text { Forgive the husband so that } \\
\text { the family does not know the } \\
\text { situation. }\end{array}$ \\
\end{tabular} & 2,74 & 0,73 & M \\
\hline & $\begin{array}{|ll|}\text { 7. } & \text { Believe the husband has a } \\
\text { reason for his actions. }\end{array}$ & 2,77 & 0,84 & M \\
\hline & 8. Can forgive by itself. & 2,81 & 0,70 & $\mathrm{M}$ \\
\hline & $\begin{array}{ll}\text { 9. } & \text { Approach your husband by } \\
\text { speaking softly }\end{array}$ & 2,77 & 0,92 & M \\
\hline \multirow{11}{*}{$\begin{array}{l}\text { Revenge } \\
\text { Motivations } \\
\text { (11) }\end{array}$} & $\begin{array}{l}\text { 10. Never shout to ask another } \\
\text { party to process the } \\
\text { husband's actions legally. }\end{array}$ & 2,77 & 0,76 & M \\
\hline & $\begin{array}{l}\text { 11. See the good side of the } \\
\text { husband. }\end{array}$ & 2,74 & 0,89 & M \\
\hline & $\begin{array}{l}\text { 12. Do not regret marrying a } \\
\text { husband. }\end{array}$ & 2,52 & 0,89 & M \\
\hline & $\begin{array}{l}\text { 13. Believe the husband has a } \\
\text { reason for the action. }\end{array}$ & 2,65 & 0,84 & M \\
\hline & 14. Life events are God's destiny. & 2,74 & 0,63 & M \\
\hline & $\begin{array}{l}\text { 15. Not reporting acts of } \\
\text { husband's violence, because } \\
\text { he believes the husband still } \\
\text { loves me. }\end{array}$ & 2,84 & 0,69 & M \\
\hline & $\begin{array}{l}\text { 16. Can eliminate pain and hate } \\
\text { by remembering his } \\
\text { kindness. } \\
\end{array}$ & 2,94 & 0,81 & M \\
\hline & 17. Do not put up a fight. & 2,74 & 0,93 & $\mathrm{M}$ \\
\hline & $\begin{array}{l}\text { 18. Don't want something bad to } \\
\text { happen to your husband. }\end{array}$ & 2,55 & 0,89 & M \\
\hline & \begin{tabular}{|l|}
$\begin{array}{l}\text { 19. Choosing to survive in the } \\
\text { household. }\end{array}$ \\
\end{tabular} & 2,81 & 0,79 & $\mathrm{M}$ \\
\hline & 20. Do not want the place where & 3,00 & 0,82 & $\mathrm{M}$ \\
\hline
\end{tabular}




\begin{tabular}{|c|c|c|c|c|}
\hline \multirow{3}{*}{ Sub Variable } & \multirow[b]{2}{*}{ Statement } & \multicolumn{2}{|c|}{ Score } & \multirow[b]{2}{*}{ Category } \\
\hline & & Mean & SD & \\
\hline & $\begin{array}{l}\text { the husband works to know } \\
\text { his actions. }\end{array}$ & & & \\
\hline \multirow{8}{*}{$\begin{array}{l}\text { Benevolence } \\
\text { Motivations } \\
\text { (8) }\end{array}$} & $\begin{array}{l}\text { 21. Keep paying attention to } \\
\text { your husband even if he is } \\
\text { treated harshly. }\end{array}$ & 2,90 & 0,65 & $\mathrm{M}$ \\
\hline & $\begin{array}{l}\text { 22. Keep preparing food for } \\
\text { husband. }\end{array}$ & 2,74 & 0,73 & M \\
\hline & $\begin{array}{l}\text { 23. Greetings when leaving / } \\
\text { returning from work. }\end{array}$ & 2,77 & 0,67 & M \\
\hline & $\begin{array}{l}\text { 24. Meeting sexual needs } \\
\text { becomes a unified } \\
\text { relationship after a fight. }\end{array}$ & 2,74 & 0,73 & M \\
\hline & $\begin{array}{l}\text { 25. Not ignoring husband's } \\
\text { requests. }\end{array}$ & 3,00 & 0,77 & M \\
\hline & $\begin{array}{l}\text { 26. Keep being nice and forget } \\
\text { the events that have passed. }\end{array}$ & 2,68 & 0,83 & M \\
\hline & $\begin{array}{l}\text { 27. Continue to accompany her } \\
\text { husband everywhere. }\end{array}$ & 2,81 & 0,75 & M \\
\hline & $\begin{array}{l}\text { 28. Not repaying a husband's } \\
\text { actions because he believes } \\
\text { God will repay him. }\end{array}$ & 3,35 & 0,55 & $\mathrm{H}$ \\
\hline
\end{tabular}

Based on the above table, it is clearly seen that based on the statement items regarding forgiveness of domestic violence, it can be seen that the forgiveness of all victims of domestic violence on all statement items is in the moderate category (M), which means that victims of domestic violence in Aceh in particular have a fairly good forgiveness level and they belong to victims of domestic violence which easily gives forgiveness to perpetrators of domestic violence. Seen in the avoidance motivations sub variable, it appears that item no.5 regarding victims asks families to reconcile themselves and their husbands in case of conflict. This is in line with (Nadia, Jannah, \& Bustamam, 2017) which says that in dealing with conflicts in the household sometimes a husband and wife pair takes the middle way in resolving it, the middle road involves the help of others, such as the family to be discussed together in order to get peace and solutions to be together.

Then in the revenge motivations sub variable in item no.12 about the victim does not regret having married her husband and no.13 about the victim believes the husband has a reason for his actions, both of these items have a lower mean value than the other items, this is because the victim of domestic violence can only harbor such feelings only to maintain the integrity of the household, this can be seen from item no.12 and no.13 which choose "very appropriate" is dominated by victims of domestic violence who have jobs. The possibility of the victim feels they have to defend their household is due to other factors, such as the presence of a child, shame on the family, the length of marriage that has been fostered together, so they actually want to end the relationship but because the above factors are very supportive for them to survive, it in line with (Dewi \& Hartini, 2017; Hannon, Finkel, Kumashiro, \& Moore, 2011; Hidayatullah \& Argiati, 2013; Lindgren \& Renck, 2009; Yusuf \& Latifa, 2017) who say that other factors that can affect forgiveness are the presence factors children, commitments that have been fostered in the household, pity for in-laws and fear of the offender.

In the benevolence motivations sub-variable one of the statements is in the high category $(\mathrm{H})$, where the item statement contains "I believe God gave a response to my husband's rude treatment of me, so I don't need to reply". This statement is very much in line with how obedience of a wife to religion, they think all what they experience will be intervened by God, without having to reciprocate with actions that are not commendable too. This is in line with Hidayatullah \& Argiati (2013) which says that one that affects forgiveness of victims of domestic violence is the element of religiosity.

Aceh is famous for its obedience to religion and highly upholds its culture and customs (Arifin, 2016). The people of Aceh are known to be predominantly Muslim, have customs and customs and are rich in various cultures (Marzuki, 2010). In Acehnese culture there is the term "meutuah" which means someone who is kind and obedient. Wives in Aceh if given the label "meutuah" by their husband, immediate family then they will feel very happy. The word "meutuah" is also likened to someone who is very good in any aspect, including religiosity. The existence of cultural and religious factors to maintain the household, belief in 
religion that does not allow people to divorce (Dewi \& Hartini, 2017). Wives in Aceh carry out their role in the household by upholding religious values, this is in line with (Yussoff, Awang, \& Ibrahim, 2014) which states that the Acehnese people make Islam as a way of life that can be implemented by all residents who diverse majority of Islam.

The problems that occur if the forgiveness of victims of domestic violence is too high, it will have an impact on the victims themselves. Where if the level of violence is already in a severe stage, it will have fatal consequences, such as death (Manumpahi, Goni, \& W., 2016). Then if forgiveness is too low it will also result in increased divorce rates. Many cases of domestic violence that cause divorce and some are still defending it by giving forgiveness (forgiveness) to perpetrators of domestic violence (Hanita, Suswandari, \& Febiana, 2009).

\section{Conclusion}

Forgiveness of victims of domestic violence is an apology for victims of domestic violence to perpetrators of domestic violence, they eliminate pain, revenge, are indifferent to victims, and continue to foster good relations and do not avoid victims. It is not easy for victims of domestic violence to give forgiveness to the perpetrators. There are factors that support victims to do this. Some of these factors are the economic dependence of the victim on the offender, long-standing marriage commitments making it easy for victims to give forgiveness, the religious factor of a victim and other supporting factors can also be caused because the victim is embarrassed to report the case, they assume that the case is a disgrace for family, the presence of children in the family and shame towards family, friends, and the surrounding community. In Aceh culture the forgiveness of victims of domestic violence can be said to be high, victims of domestic violence are very easy in giving forgiveness to perpetrators. In Aceh the word "meutuah" is a term that is very desirable if a wife is given such a label, because the word has a very deep meaning for a wife, is considered a very good wife, loyal, obedient, and when involved in a relationship, she tends give everything.

\section{References}

Afdal, Alizamar, Ifdil, Erlamsyah, \& Taufik. (2017). Guidance and Counseling Services for Women Victims of Domestic Violence. Advances in Social Science, Education and Humanities Research, 118, 935-939.

Alizamar, Ifdil, Fadli, R. P., Erwinda, L., Zola, N., Churnia, E., ... Rangka, I. B. (2018). The Effectiveness of Hypnotherapy In Reducing Stress Levels. Addictive Disorders \& Their Treatment. Addictive Disorders \& Their Treatment, 174), 191-195.

Arifin, M. (2016). Islam dan Alkulturasi Budaya Lokal di Aceh (Studi Terhadap Ritual Rah Ulei di Kuburan dalam Masyarakat Pidie Aceh). Jurnal IImiah Islam Futura, 15(2), 251-284.

Ariyani, M., \& Qonita, M. (2018). Perbandingan Forgiveness Pada Wanita Korban KDRT Ditinjau dari Kehadiran Anak. Jurnal Penelitian Dan Pengukuran Psikologi, 71 ), 20-25.

Basri, S.Kasim, S., \& Roslan, S. (2018). Kekerasan dalam Rumah Tangga (KDRT) Yang Dialami Suami. Jurnal Pemikiran Dan Penelitian Sosiologi, 3(2), 457-466.

Dewi, I. D. A. D. P., \& Hartini, N. (2017). Dinamika Forgiveness Pada Istri Yang Mengalami Kekerasan dalam Rumah Tangga (KDRT). Jurnal Psikologi Dan Kesehatan Mental, 2(1), 51-62. http://doi.org/10.20473/jpkm.v2i12017.51-62

Elvinawanty, R., \& Mailani, L. (2016). Forgiveness Ditinjau dari Empathy Pada Pasangan Suami Istri di Kelurahan Binjai kecamatan Medan Denai. Jurnal Tarbiyah, 23(2), 370-379.

Hanifah, A. (2007). Permasalahan Kekerasan dalam Rumah Tangga dan Alternatif Pemecahannya. Jurnal Penelitian Dan Pengembangan Kesejahteraan Sosial, 12(3), 45-56.

Hanita, M., Suswandari, \& Febiana. (2009). Buku Panduan Proses Hukum Kekerasan dalam Rumah Tangga. Jakarta: P2TP2A.

Hannon, P. A., Finkel, E. L. I. J., Kumashiro, M., \& Moore, H. (2011). The Soothing Effects of Forgiveness On Victims ' and Perpetrators 'Blood Pressure. Journal of the International Association for Relationship Research, 1011), 1-11. http://doi.org/10.1111/j.1475-6811.2011.01356.x

Hidayatullah, S., \& Argiati, S. H. B. (2013). Dinamika Psikologi dan Perilaku Forgiveness Bagi Korban Kekerasan dalam Rumah Tangga. Jurnal Spirits, 4(1), 74-80. 
Hossain, A. (2016). Sociology and Criminology-Open Access The Impact of Domestic Violence On Women : A Case Study of Rural. Jurnal Social Crimonol, 4(1), 2-8. http://doi.org/10.4172/2375-4435.1000135

Jampolsky, G. G. (2001). Rela Memaafkan Obat Paling Ampuh. Jakarta: Penertbit Erlangga.

Jayanthi, E. T. (2009). Faktor-Faktor Penyebab Terjadinya Kekerasan dalam Rumah Tangga Pada Survivor Yang Ditangani Oleh Lembaga Sahabat Perempuan Magelang. Jurnal Dimensia, 3(2), 33-50.

Kaur, R., \& Garg, S. (2008). Addressing Domestic Violence Against Women: An Unfinished Agenda. Indian Journal of Community Medicine, 33(2), 73-76.

Leo, N. (2010). Sulitnya Menyatukan Dua Perbedaan dalam Perkawinan. Retrieved from http://www.tribunnews.com/lifestyle/2010/10/04/sulitnya-menyatukan-dua-perbedaan-dalamperkawinan

Lindgren, M. S., \& Renck, B. (2009). Intimate Partner Violence and The Leaving Process : Interviews With Abused Women. International Journal of Qualitative Studies on Health and Well-Being, 3(2), 113-124. http://doi.org/10.1080/17482620801945805

Maisah. (2016). Rumah Tangga dan HAM : Studi Atas Trend Kekerasan dalam Rumah Tangga di Provinsi Jambi. Jurnal Musawa, 15(1), 435-438.

Manumpahi, E., Goni, S. Y. V. I., \& W., H. (2016). Kajian Kekerasan dalam Rumah Tangga Terhadap Psikologi Anak di Desa Soakonora Kecamatan Jailolo Kabupaten Halmahera Barat. E-Jounal Acta Diurna, 5(1), 115.

Marzuki. (2010). Tradisi Peusijuek dalm Masyarakat Aceh: Integritas Nilai-Nilai Agama dan Budaya(Vol. 3).

Mccullough, M. E. (2001). Forgiveness: Who does it and how do they do it? Current Directions in Psychological Science, 106), 194-197.

Mccullough, M. E., Fincham, F. D., \& Tsang, J. (2003). Forgiveness , Forbearance , and Time: The Temporal Unfolding of Transgression-Related Interpersonal Motivations. Journal of Personality and Social Psychology, 84(3), 540-557. http://doi.org/10.1037/0022-3514.84.3.540

Mccullough, M. E., Rachal, K. C., Sandage, S. J., Worthington, E. L., Brown, S. W., \& Hight, T. L. (1998). Interpersonal Forgiving In Close Relationships: II . Theoretical Elaboration and Measurement. Journal of Personality and Social Psychology, 75(6), 1586-1603.

Munawwar, Muhammad, R. A., \& Sjafei, M. S. (2013). Perkawinan Beda Agama Yang Dilakukan di Luar Negeri Berdasarkan Undang-Undang Perkawinan di Indonesia. Jurnal IImu Hukum, 2(2), 37-45.

Nadia, Jannah, N., \& Bustamam, N. (2017). Hubungan Resolusi Konflik Pasangan Suami Istri Bekerja dengan Kepuasan Pernikahan pada Usia Pernikahan 3-5 Tahun. Jurnal Bimbingan Konseling Universitas Syiah Kuala, 2(2), 22-31.

Namamia. (2015). Sifat dan Karakter Meutuah. Retrieved from https://www.google.com/amp/s/namamia.com/amp/arti-nama/meutuah.html

Nashori, F. (2012). Pemaafan Pada Etnis Jawa: Pengaruh Religiositas dan Keterikatan Interpersonal Terhadap Pemaafan Melalui Perantara Sifat Kebersetujuan dan Neurotisme (Studi Pada Warga Yogyakarta). Program Pasca Sarjana Universitas Padjadjaran. Retrieved from https://dspace.uii.ac.id/bitstream/handle/123456789/5900/NASKAH

PUBLIKASI.pdf?sequence=2\&isAllowed=y

Nashori, F. (2014). Psikologi Pemaafan. Yogyakarta: Safiria Insania Press.

Nurrachmawati, A., Nurohma, \& Rini, P. M. (2013). Potret Kesehatan Perempuan Korban Kekerasan dalam Rumah Tangga (Studi Kasus di Pusat Pelayanan Terpadu Pemberdayaan Perempuan dan Anak Kalimatan Timur). Jurnal Kesehatan Reproduksi, 3(1), 24-37.

P2TP2A. (2019). Bentuk-bentuk Kekerasan Terhadap Perempuan di Provinsi Aceh. Banda Aceh. 
Pasalbessy, J. D. (2010). Dampak Tindak Kekerasan Terhadap Perempuan dan Anak Serta Solusinya. Jurnal Sasi, 16(3), 8-13.

Prianto, B., Wulandari, N. W., \& Rahmawati, A. (2013). Rendahnya Komitmen dalam Perkawinan Sebagai Sebab Perceraian. Jurnal Komunitas, 5(2), 208-218.

Rahayu, N. D. (2019). Memaafkan dan Komitmen Pernikahan Pada Istri Setelah Diselingkuhi Oleh Suami. EJounal Pskologi, 72$), 180-193$.

Ramadani, M., \& Yuliani, F. (2015). Kekerasan dalam Rumah Tangga (KDRT) Sebagai Salah Satu Isu Kesehatan Masyarakat Secara Global. Jurnal Kesehatan Masyarakat Andalas, 9(2), 80-87.

Rofiah, N. (2017). Kekerasan dalam Rumah Tangga dalam Perspektif Islam, 2(1), 31-44. http://doi.org/10.15575/jw.v2i1.829

Saidiyah, S., \& Julianto, V. (2016). Problem Pernikahan dan Strategi Penyelesaian : Studi Kasus Pada Pasangan Suami Istri Dengan Usia Perkawinan di Bawah Sepuluh Tahun. Jurnal Psikologi Undip, 15(2), 124-133.

Santoro, C., Martínez-Ferrer, B., Gimeno, C. M., \& Musitu, G. (2018). New Directions For Preventing Dating Violence In Adolescence: The Study Of Gender Models. Jurnal Frontiers in Psychology, 9, 946.

Setiawan, C. N., Bhima, S. K. L., \& Dhanardhono, T. (2018). Faktor-Faktor Yang Memengaruhi Kejadian Kekerasan dalam Rumah Tangga dan Pelaporan Pada Pihak Kepolisian. Jurnal Kedokteran Diponegoro, ス1), 127-139.

Sumiati, I., \& Sandjaja, S. S. (2013). Hubungan Antara Memaafkan Dengan Kematangan Diri Pada Remaja Akhir. Jurnal Noetic Psychology, 3(2), 144-162.

Worthington, E. L. \& W. N. G. (1999). The Psychology Of Unforgiveness and Forgiveness and Implications for Clinical Practice. Journal of Social and Clinical Psychology, 18, 385-418.

Yussoff, N. bt, Awang, M. I., \& Ibrahim. (2014). Intergrasi Nilai Islam Budaya Aceh Berdasarkan Kurikulum Karakter. Jurnal Humanus, XIII 1), 2014.

Yusuf, F. N., \& Latifa, R. (2017). The Influence of Forgiveness, Gratitude and Diration of Marriage Toward Marital Satisfaction on Wifes In South Jakarta. Journal of PSychology, 22(2), 232-240.

Zikra, Z. (2019). Chronotherapy for Women Victims of Domestic Violence Chronotherapy Untuk Wanita Korban Kekerasan dalam Rumah Tangga. In Jurnal Penelitian Pendidikan Indonesia (Vol. 5, pp. 20-23). 